\title{
Plant and microbial-induced changes in $P$ pools in soil amended with straw and inorganic $P$
}

\author{
Khuyen Thi Kim Hoang ${ }^{1,2}$ and Petra Marschner ${ }^{1 *}$ \\ ${ }^{1}$ School of Agriculture, Food and Wine, The University of Adelaide, Adelaide SA 5005, Australia. ${ }^{2}$ Chemical \\ Engineering Faculty, Industrial University of Ho Chi Minh, HCMC 7000, Vietnam. *Corresponding author: \\ petra.marschner@adelaide.edu.au
}

\begin{abstract}
The aim of this study was to determine the effect of soil amendments on P pools and their depletion by plants and microbes. The experiment was divided into two parts. In Part A, barley straw (C/P 255) was added alone or with inorganic $\mathrm{P}$ to reduce the $\mathrm{C} / \mathrm{P}$ ratio to 127 or 25 (straw treatments). In three other treatments, the same amount of $\mathrm{P}$ was added as in the straw treatments as inorganic $\mathrm{P}$ (fertilizer treatments). The soil was incubated for three weeks. Then (Part B), wheat was grown for five weeks in one set of soils. Barley straw was added to another set to increase microbial growth and incubated moist for three weeks. P pools were measured at the end of Part A and Part B. At the end of Part A all P pools increased with P addition rate. P pools were greater in the fertilizer than the straw treatments except for microbial biomass $\mathrm{P}$ (MBP) which was greater in the straw treatments. After wheat growth, $\mathrm{HCl}-\mathrm{P}$, phosphatase-P, citrate- $\mathrm{P}, \mathrm{CaCl}_{2}-\mathrm{P}$ were depleted compared to Part A, MBP was higher. Addition of barley straw in Part B induced depletion of HCl-P, and citrate-P, but increased phosphatase-P, $\mathrm{CaCl}_{2}-\mathrm{P}$ and MBP. It is concluded that the size of the $\mathrm{P}$ pools is mainly influenced by $\mathrm{P}$ addition rate not form in which $\mathrm{P}$ is added. The impact of growing plants on $\mathrm{P}$ pools differs from that of microbes stimulated by high $\mathrm{C} / \mathrm{P}$ straw addition.
\end{abstract}

Keywords: Accumulation, C/P ratio, depletion, $\mathrm{P}$ pools, straw 


\section{Introduction}

Phosphorus is an essential nutrient for all living organisms (Tiessen et al., 2011), but $\mathrm{P}$ fertilizer resources are finite, therefore $\mathrm{P}$ management in cropping systems is important for future food security. To optimize P management and improve $\mathrm{P}$ use efficiency an understanding of $\mathrm{P}$ pools and their changes in soil is necessary (Balemi and Negisho, 2012). In soils, $\mathrm{P}$ is present in different inorganic and organic pools with varying availability. Changes in $\mathrm{P}$ pools in the soil-plant system are a function of $\mathrm{P}$ transformations and utilisation which are affected by soil properties (Alamgir and Marschner, 2016, Chatterjee et al., 2014) rhizosphere, and plant processes (Pierzynski et al., 1990, Shen et al., 2011, Ciampitti et al., 2011). It has been shown that the effect of crop residues on $\mathrm{P}$ availability and $\mathrm{P}$ pools depends on their $\mathrm{C} / \mathrm{P}$ ratio (Dalal, 1979). Crop residues with $\mathrm{C} / \mathrm{P}>200$ induce net $\mathrm{P}$ immobilisation and depletion of $\mathrm{P}$ pools, residues with lower $\mathrm{C} / \mathrm{P}$ ratio increase $\mathrm{P}$ availability and P pools (Alamgir et al., 2012). Maltais-Landry and Frossard (2015) found that residues or water-soluble $\mathrm{P}$ fertilizer added at $15 \mathrm{mg} \mathrm{kg}^{-1}$ had similar effects on microbial and resin $\mathrm{P}$ and plant $\mathrm{P}$ uptake. However, it is unclear if $\mathrm{P}$ added at different rates as combination of crop residues and inorganic $\mathrm{P}$ or inorganic $\mathrm{P}$ alone differ in their effect on soil $\mathrm{P}$ pools and subsequent changes in $\mathrm{P}$ pools induced by plants or microbes. Organic amendments are likely to increase microbial growth and synthesis of organic $\mathrm{P}$ forms whereas fertilizer P may increase mainly inorganic P pools. But it is unclear if plants or microbes stimulated by straw addition differ in their influence on $\mathrm{P}$ pools in soil amended with organic or inorganic $\mathrm{P}$ amendments.

The Hedley $\mathrm{P}$ fractionation scheme is often used to assess soil P pools (Hedley et al., 1982). But it is time consuming and involves concentrations of extractants that are unlikely to occur in soils. DeLuca et al. (2015) recently introduced a simplified method to determine biologically available $\mathrm{P}$ pools. The method involves parallel extraction of soil with $\mathrm{CaCl}_{2}$, citrate, phosphatase and $\mathrm{HCl}$. DeLuca et al. (2015) consider these pools as biologically available because roots or microbes may release organic acid anions, phosphatase or protons and thus access these pools. However, it is not clear if the pools assessed by the DeLuca method are indeed available to plants and microbes.

The aims of this study were to assess (i) changes in $\mathrm{P}$ pools after addition of $\mathrm{P}$ as high $\mathrm{C} / \mathrm{P}$ cereal straw, cereal straw plus inorganic $\mathrm{P}$ to reduce $\mathrm{C} / \mathrm{P}$ ratio or inorganic $\mathrm{P}$ alone, and (ii) changes in these $\mathrm{P}$ pools by plants or microbes stimulated by high $\mathrm{C} / \mathrm{P}$ straw addition. The hypotheses were (1) at a given $\mathrm{P}$ addition rate, the treatments with straw will induce a higher concentration of phosphatase extractable $\mathrm{P}$ and MBP than the treatments with inorganic P only, and (2) subsequent plant growth will induce depletion of all $\mathrm{P}$ pools whereas stimulation of microbes by straw addition will lead to build-up of microbial and phosphatase extractable $P$.

\section{Materials and Methods}

A loamy sand was collected from 0 to $10 \mathrm{~cm}$ on Waite Campus, The University of Adelaide, South Australia (Longitude $138^{\circ} 38^{\prime} \mathrm{E}$, Latitude $35^{\circ} 6^{\prime} \mathrm{S}$ ) which had been under permanent pasture over 80 years. The soil was used because previous studies had shown that $\mathrm{P}$ pools in this soil changed after amendment with organic materials (Elmajdoub, personal communication). The soil was dried at $40^{\circ} \mathrm{C}$ and passed through a $2 \mathrm{~mm}$ sieve. This temperature is not unusual because in South Australia, surface soils are often exposed to temperatures exceeding $40^{\circ} \mathrm{C}$ during summer. The properties of the soil are as follows: $\mathrm{pH} 6.8$ (1:5 soil/water); clay 
25\%; sand 37\%; silt 37\%; total P $302 \mathrm{mg} \mathrm{kg}^{-1} ; \mathrm{pH}$ (1:5) 5.6, EC (1:5) $0.1 \mathrm{dS} \mathrm{m}^{-1}$, total organic C $17 \mathrm{~g}$ $\mathrm{kg}^{-1}$, total organic $\mathrm{N} 1.5 \mathrm{~g} \mathrm{~kg}^{-1}$, bulk density $1.3 \mathrm{~g} \mathrm{~cm}^{-}$ ${ }^{3}$, maximum water-holding capacity $349 \mathrm{~g} \mathrm{~kg}^{-1}$. The properties of the mature barley straw (finely ground and sieved to particle size of $0.25-2 \mathrm{~mm}$ ) used in this experiment were: total $\mathrm{P} 1.6 \mathrm{~g} \mathrm{~kg}^{-1}$; total $\mathrm{N} 4.3 \mathrm{~g} \mathrm{~kg}^{-1}$; total $\mathrm{C} 408 \mathrm{~g} \mathrm{~kg}^{-1} ; \mathrm{C} / \mathrm{P}$ ratio 255 and $\mathrm{C} / \mathrm{N}$ ratio 95 .

\subsection{Experimental design}

The soil was pre-incubated for 10 days at $50 \%$ waterholding capacity. Previous studies with this soil had shown that at this water content soil respiration as indicator of microbial activity is maximal (Marschner et al., 2015) and wheat grows well (Xue et al., 2016). The experiment included seven treatments with four replicates each. The control was unamended. There were three treatments with barley straw $\left(20 \mathrm{~g} \mathrm{~kg}^{-1}\right)$ : only straw (C/P 255, P added with straw $\left.32 \mathrm{mg} \mathrm{kg}^{-1}\right)$, straw $+\mathrm{KH}_{2} \mathrm{PO}_{4}$ to adjust the $\mathrm{C} / \mathrm{P}$ ratio to 127 or 25 . No straw was added in the three fertilizer treatments, which received only $\mathrm{KH}_{2} \mathrm{PO}_{4}$ at the same amount of $\mathrm{P}$ as in the straw treatments (straw + inorganic P). For treatment names and inorganic $\mathrm{P}$ addition rates see Table 1. To provide sufficient $\mathrm{N}$ for straw decomposition, all treatments received $1.3 \mathrm{~g} \mathrm{KNO}_{3} \mathrm{~kg}^{-1}$ soil to adjust the $\mathrm{C} / \mathrm{N}$ ratio of the straw treatments to 30 . Residues and inorganic nutrients were mixed thoroughly into the soil.

Table 1. Treatment names, $\mathrm{C} / \mathrm{P}$ ratio, barley straw and inorganic $\mathrm{P}$ added $\left(\mathrm{mg} \mathrm{kg}^{-1}\right)$.

\begin{tabular}{cccc}
\hline Control & & - & 0 \\
S255 & 255 & + & 0 \\
S127 & 127 & + & 32 \\
S25 & 25 & + & 288 \\
P255 & & - & 32 \\
P127 & & - & 64 \\
P25 & & - & 320 \\
\hline
\end{tabular}

*P added with straw $32 \mathrm{mg} \mathrm{kg}^{-1}$

Then, two experimental units were set up. One unit in pots (400 $\mathrm{g}$ soil per pot) to assess changes in $\mathrm{P}$ pools after plant growth and a second unit in cores (30 g core) to determine changes in P pools by soil microbes. Cores were used because they have a mesh bottom to ensure adequate aeration.

Soil (400 g dry weight equivalent) was placed in $1 \mathrm{~L}$ pots lined with plastic bags. PVC cores with $3.7 \mathrm{~cm}$ diameter, $5 \mathrm{~cm}$ height and a nylon mesh base $(7.5 \mu \mathrm{m}$,
Australian Filter Specialist) were filled with $30 \mathrm{~g}$ soil (dry weight equivalent, bulk density adjusted to 1.3 $\left.\mathrm{g} \mathrm{cm}^{-3}\right)$. Pots and cores were incubated in the dark at 22-25 ${ }^{\circ} \mathrm{C}$ for 21 days to allow formation of P pools. During incubation, soil moisture was maintained at $50 \%$ of WHC by weighing pots and cores regularly and adding water if necessary. This 21-day period is referred to as Part A. The soil was incubated for three weeks because previous studies in our lab with the 
same soil (Elmajdoub, personal communication) had shown that after organic amendments, the size of soil $\mathrm{P}$ pools increases for three weeks, but then remains stable. At the start of the following Part B, 10 pregerminated wheat seeds (Triticum aestivum L., variety Axe) were planted in the pots and then grown for five weeks in a glasshouse. The temperature in the glasshouse during the experiment ranged from 25 to $35^{\circ} \mathrm{C}$. For the cores, barley straw $\left(10 \mathrm{~g} \mathrm{~kg}^{-1}\right)$ was thoroughly mixed into the soil at the start of Part B to stimulate microbial growth. The soil was incubated for 3 weeks. This period is referred to as Part B. Soil water content was maintained at $50 \% \mathrm{WHC}$ by weight with reverse osmosis water. During wheat growth (Part B), pots were watered daily. In Part A and in the cores in Part B, soil water content changed more slowly and was adjusted every 2-3 days.

\subsection{Analyses}

Soil texture was determined by the hydrometer method (Gee and Or, 2002). Soil maximum water holding capacity was measured using a sintered glass funnel connected to a $1 \mathrm{~m}$ water column (Wilke, 2005). Soil $\mathrm{pH}$ was measured after $1 \mathrm{~h}$ end-over-end shaking in a 1:5 soil:water ratio. Total organic carbon of residues was determined by $\mathrm{K}_{2} \mathrm{Cr}_{2} \mathrm{O}_{7}$ and $\mathrm{H}_{2} \mathrm{SO}_{4}$ oxidation by titration with acidified $\left(\mathrm{NH}_{4}\right)_{2} \mathrm{Fe}\left(\mathrm{SO}_{4}\right)_{2} \cdot 6 \mathrm{H}_{2} \mathrm{O}$ (Walkley and Black, 1934). Total P in soil was determined by the phosphovanado molybdate method (Hanson, 1950) after acid digestion with nitric acid-perchloric acid at a 4:1 ratio (Olsen et al., 1982). Total $\mathrm{P}$ of shoot and plant residues was digested with nitric acid and $\mathrm{H}_{2} \mathrm{O}_{2}$ at a 4:1 ratio and also determined by the phosphovanado molybdate method (Hanson, 1950). Total $\mathrm{N}$ in straw was measured by a modified Kjeldahl method (Bremner and Breitenbeck, 1983).

At the end of Part A and Part B the following properties were determined. Soil available N (ammonium and nitrate) concentration was measured after $1 \mathrm{~h}$ endover-end shaker with $2 \mathrm{M} \mathrm{KCl}$ at 1:5 soil extractant ratio. Ammonium-N was determined by Willis et al. (1996) and nitrate-N as described in Miranda et al. (2001). Available P in soil was extracted by the anion exchange resin method (Kouno et al., 1995). This method was also used to determine MBP, but using hexanol instead of chloroform as fumigant. The P concentration was determined colorimetrically (Murphy and Riley, 1962). MBP was calculated as the difference between available $\mathrm{P}$ and $\mathrm{P}$ extracted with hexanol. Soil $\mathrm{P}$ pools were determined according to Deluca et al. (2015) using four extractants in parallel, including $10 \mathrm{mM}$ citric acid, $1 \mathrm{M} \mathrm{HCl}, 10 \mathrm{mM} \mathrm{CaCl}_{2}$ and 0.2 enzyme unit phosphatase (from wheat germ) extractable P. Moist soil equivalent to $0.5 \mathrm{~g}$ dry soil were shaken with $10 \mathrm{ml}$ of each extractant separately for $3 \mathrm{hrs}$ (DeLuca et al., 2015). P in the extracts was determined by the malachite-green method (Ohno and Zibilske, 1991).

\subsection{Statistical analysis}

Data were analysed separately for pots and cores by one-way ANOVA for each sampling time with Genstat $15^{\text {th }}$ edition (VSN Int. Ltd., UK). Tukey's multiple comparison tests at $95 \%$ confidence interval was used to determine significant differences among treatments.

\section{Results}

At the end of the 3-week incubation (Part A), the size of all $\mathrm{P}$ pools increased with $\mathrm{P}$ addition rate (Figures 1, 2; for treatment names and details see Table 1). HCl-P was the largest pool, followed by citrate-P and resin $\mathrm{P}$. Phosphatase $\mathrm{P}, \mathrm{CaCl}_{2}-\mathrm{P}$ and microbial $\mathrm{P}$ were up to 10-fold lower than HCl-P. At the lowest $\mathrm{P}$ addition rate (S255 and $\mathrm{P} 255$ ), most $\mathrm{P}$ pools were similar as the control, except for MBP in S255 which 
was about two-fold higher than the control. Most P pools (except MBP) were greater in P127 and P25 than the respective straw treatments $(\mathrm{S} 127, \mathrm{~S} 25)$.
In contrast, $\mathrm{MBP}$ at a given $\mathrm{P}$ addition rate was about two-fold higher in the straw than the fertilizer treatments.
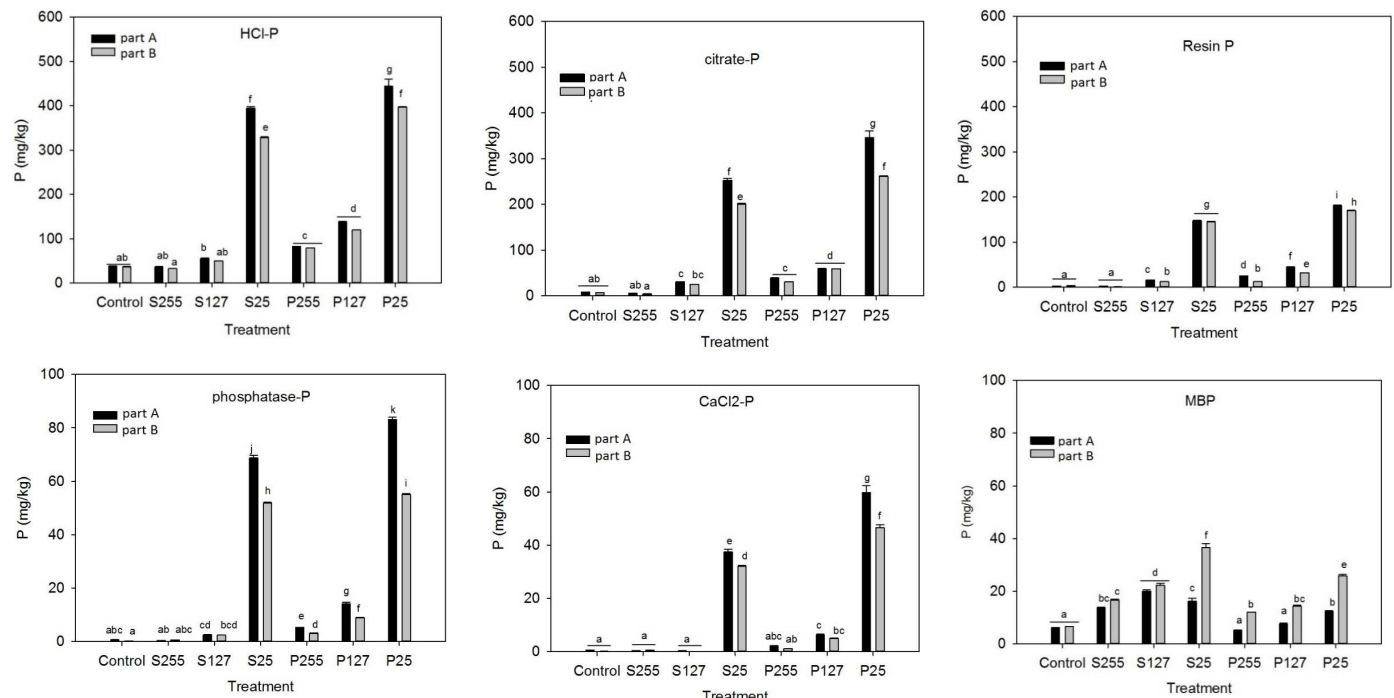

Figure 1. Concentration of $\mathrm{P}$ pools at the end of the three-week incubation (part A) and after five weeks growth of wheat (part B) in soil amended at the start of Part A with straw (S255, S127, S25) or inorganic P (P255, P127, P25). For treatments see Table 1. For each part, bars with different letters are significantly different $(\mathrm{n}=4, \mathrm{P} \leq 0.05)$. Vertical lines indicate standard errors.
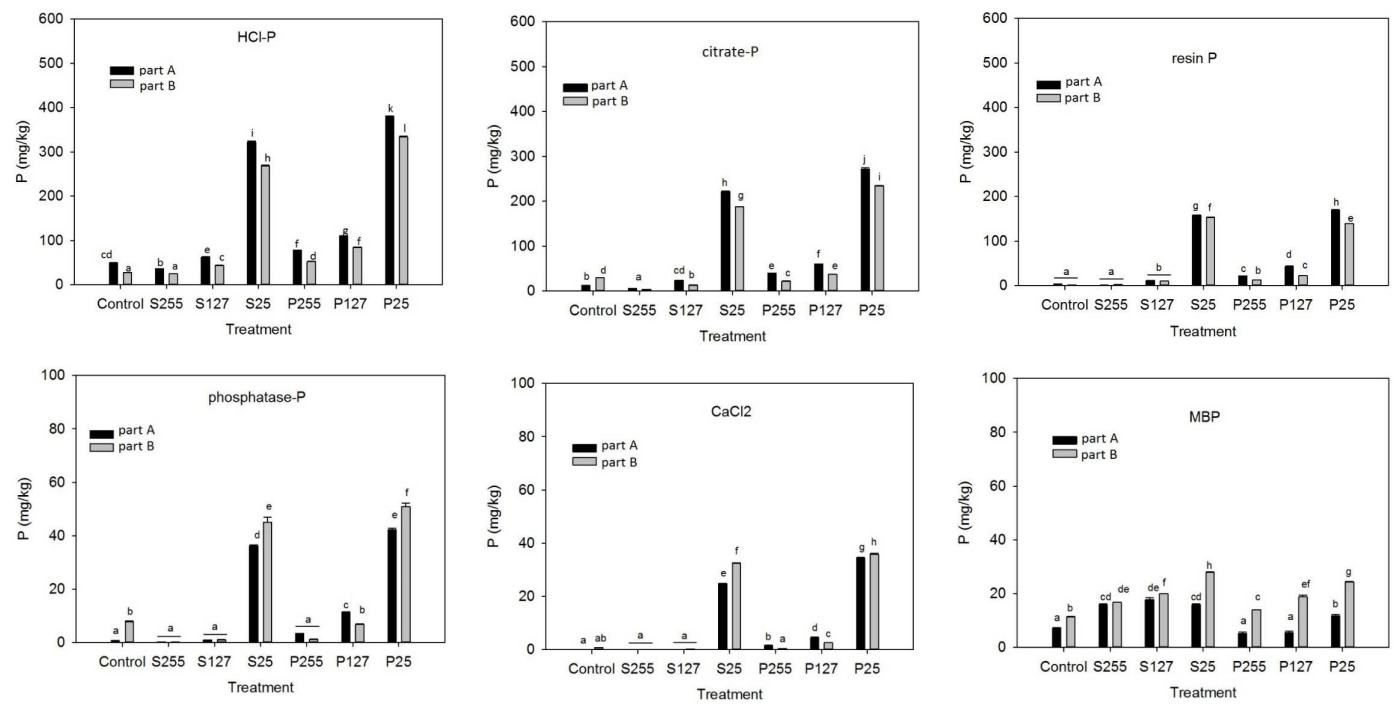

Figure 2. Concentration of $\mathrm{P}$ pools at the end of the first 3-week incubation (part A) and after the second 3-week incubation with straw (part B). In soil amended at the start of Part A with straw (S255, S127, S25) or inorganic P (P255, P127, P25). For treatments see Table 1. For each part, bars with different letters are significantly different $(n=4, P \leq 0.05)$. Vertical lines indicate standard errors. 
After growing wheat for five weeks (Part B), HCl-P, citrate-P, phosphatase $\mathrm{P}, \mathrm{CaCl} 2-\mathrm{P}$ in $\mathrm{S} 25$ and $\mathrm{P} 25$ were $10-25 \%$ lower than at the end of part A with the largest difference in phosphatase $\mathrm{P}$ (Figure 1). This was also the case for phosphatase P in P255 and P127. Resin P was lower at the end of Part B than Part A in all fertilizer treatments. In contrast, MBP increased from Part A to Part B, in S25 and all fertilizer treatments. In S25 and P25 MBP was two-fold higher in Part B than Part A. P pools did not change from Part A to Part B in the control, S255 and S127.

Shoot dry weight was about $50 \%$ lower in straw treatments than the control whereas it was about $30 \%$ higher in the fertilizer treatments (Table 2). Root dry weight was lower in amended treatments than the control, particularly at the two highest $\mathrm{P}$ rates. The shoot/root ratio was about one in the control and was $0.5 \neg 0.8$ and $2.0-2.5$ in the straw and fertilizer treatments, respectively (data not shown). The shoot/ root ratio increased with $\mathrm{P}$ addition rate. Shoot $\mathrm{P}$ concentration was lowest in the control and S255. It increased with $\mathrm{P}$ addition rate and at a given $\mathrm{P}$ addition rate was higher in the straw than the fertilizer treatments. Shoot $\mathrm{P}$ uptake increased with $\mathrm{P}$ addition rate (Figure 3). At a given $\mathrm{P}$ addition rate, shoot $\mathrm{P}$ uptake was two to three-fold higher in fertilizer than the straw treatments. Compared to the control, shoot $\mathrm{P}$ uptake was lower in S255 and S127, 30\% higher in S25 and about two-fold higher in P255 and P127, and five-fold higher in P25.

Table 2. Shoot and root biomass ( $\mathrm{g}$ dry weight pot $^{-1}$ ) and shoot $\mathrm{P}$ concentration in wheat after five weeks growth in soil amended at the start of Part A with straw (S255, S127, S25) or inorganic P (P255, P127, P25). For treatments see Table 1 .

\begin{tabular}{cc|c|c}
\hline & $\begin{array}{c}\text { Shoot biomass } \\
\left(\mathrm{g} \mathrm{pot}^{-1}\right)\end{array}$ & $\begin{array}{c}\text { Root biomass } \\
\left(\mathrm{g} \mathrm{pot}^{-1}\right)\end{array}$ & $\begin{array}{c}\text { Shoot P concentration } \\
\left(\mathrm{g} \mathrm{kg}^{-1}\right)\end{array}$ \\
\hline Control & $0.73^{ \pm 0.06} \mathrm{~b}$ & $0.64^{ \pm 0.05} \mathrm{~b}$ & $2.32^{ \pm 0.03} \mathrm{a}$ \\
S255 & $0.28^{ \pm 0.01} \mathrm{a}$ & $0.61^{ \pm 0.02} \mathrm{~b}$ & $2.25^{ \pm 0.06} \mathrm{a}$ \\
S127 & $0.34^{ \pm 0.02} \mathrm{a}$ & $0.55^{ \pm 0.05} \mathrm{ab}$ & $3.49^{ \pm 0.09} \mathrm{~b}$ \\
S25 & $0.36^{ \pm 0.00} \mathrm{a}$ & $0.55^{ \pm 0.01} \mathrm{ab}$ & $8.02^{ \pm 0.13} \mathrm{~d}$ \\
P255 & $1.06^{ \pm 0.03} \mathrm{c}$ & $0.52^{ \pm 0.00} \mathrm{ab}$ & $3.35^{ \pm 0.06} \mathrm{~b}$ \\
P127 & $1.03^{ \pm 0.02} \mathrm{c}$ & $0.52^{ \pm 0.01} \mathrm{ab}$ & $3.62^{ \pm 0.03} \mathrm{~b}$ \\
P25 & $1.14^{ \pm 0.01} \mathrm{c}$ & $0.46^{ \pm 0.02} \mathrm{a}$ & $7.09^{ \pm 0.05} \mathrm{c}$ \\
\hline
\end{tabular}




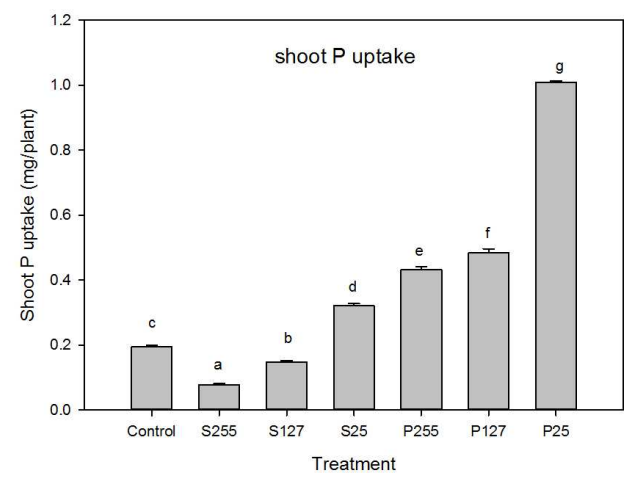

Figure 3. Wheat shoot $\mathrm{P}$ uptake (mg/plant) after five weeks growth in soil amended at the start of Part A with straw (S255, S127, S25) or inorganic P (P255, P127, P25). For treatments see Table 1 . Bars with different letters are significantly different $(n=4, P \leq 0.05)$. Vertical lines indicate standard errors.

In the cores, where microbial growth was stimulated by addition of barley straw at the start of Part B, HCl$\mathrm{P}$ and citrate-P were about $10 \%$ lower at the end of Part B than in Part A (Figure 2). For HCl-P this was the case for all treatments, for citrate-P only for the fertilizer treatments, S127 and S25. In the fertilizer treatments, resin $\mathrm{P}$ was about $10 \%$ lower in Part B than Part A. MBP was higher in Part B than Part A with a two-fold increase in all fertilizer treatments and S25. However, in contrast to the pots, phosphatase-P and $\mathrm{CaCl}_{2}-\mathrm{P}$ in $\mathrm{S} 25$ and $\mathrm{P} 25$ were up to $20 \%$ higher in Part B than Part A. In the control, HCl-P decreased from Part A to Part B whereas citrate-P, phosphatase-P and MBP increased.

Available N in Part A and Part B was lower in the straw treatments $\left(0.3-0.4 \mathrm{~g} \mathrm{~kg}^{-1}\right)$ than the control and the fertilizer treatments $\left(0.8-0.9 \mathrm{~g} \mathrm{~kg}^{-1}\right)$. The $\mathrm{pH}$ in soil with straw (6.3-6.9) was higher than $\mathrm{pH}$ in soil with fertilizer (5.8-6.3), and it was about 0.3-0.5 units higher in Part A compared to Part B.

\section{Discussion}

This study showed that $\mathrm{P}$ addition rate had a stronger effect on soil P pools at the end of Part A than the form in which $\mathrm{P}$ was added. In general, the lowest $\mathrm{P}$ addition rate did not influence $\mathrm{P}$ pools compared to the unamended control except MBP in S255 which was higher. This indicates that the straw provided enough $\mathrm{P}$ for limited microbial uptake compared to the unamended soil. The size of most $\mathrm{P}$ pools was greater in P127 and P25 than S127 and S25 except for MBP which was smaller. Greater microbial P uptake in S127 and S25 compared to P127 and P25 can only explain a small proportion of the difference between P127 and S127 in the other P pools. The greater $\mathrm{P}$ pools in the fertilizer treatments are likely due to the high solubility of $\mathrm{KH}_{2} \mathrm{PO}_{4}$ compared to $\mathrm{P}$ in straw. Although plant residues contain inorganic P (Noack et al., 2012), a large proportion is in organic form and has to be mineralised before it can enter the $\mathrm{HCl}-\mathrm{P}$, citrate- $\mathrm{P}, \mathrm{CaCl}_{2}-\mathrm{P}$ and resin $\mathrm{P}$ pools. Therefore, the first hypothesis (at a given $\mathrm{P}$ addition rate, the treatments with straw will induce a higher concentration of phosphatase extractable $\mathrm{P}$ and MBP than the treatments with $\mathrm{P}$ fertilizer only) can only be confirmed for MBP. The higher phosphatase P concentration in the fertilizer treatments indicates that inorganic $\mathrm{P}$ addition stimulated synthesis of organic P. Both $\mathrm{CaCl}_{2}-\mathrm{P}$ and resin $\mathrm{P}$ are considered to represent plant available P. But in this study, resin $\mathrm{P}$ was about four-fold higher than $\mathrm{CaCl}_{2}-\mathrm{P}$. This is likely due the removal of $\mathrm{P}$ from the extracting solution by the resin which induced release of labile $\mathrm{P}$ from soil particles. When the soil is shaken with $\mathrm{CaCl}_{2}, \mathrm{P}$ will remain in solution and not result in a concentration gradient-induced release of labile $\mathrm{P}$. 
The first part of the second hypothesis (subsequent plant growth will induce depletion of all $\mathrm{P}$ pools whereas stimulation of microbes by straw addition will lead to build-up of microbial and phosphatase extractable P) cannot be confirmed because plant growth did not deplete resin P and increased MBP. However, the second part of the hypothesis can be confirmed. In the cores, where straw was added at the start of both Part A and Part B, phosphatase P and MBP where higher at the end of Part B than Part A. This can be explained by the second straw addition at the start of Part B which stimulated microbial growth resulting in higher microbial $\mathrm{P}$ uptake and phosphatase labile P (likely microbial metabolites).

Wheat growth induced a decrease of about $10 \%$ in HCl-P, citrate-P and phosphatase $\mathrm{P}$ which can be explained by plant $\mathrm{P}$ uptake and transformation into other pools. Resin $\mathrm{P}$ did not change and $\mathrm{CaCl}_{2}-\mathrm{P}$ changed little from Part A to Part B. These P pools are considered to be plant-available (DeLuca et al., 2015, Hedley et al., 1982) and therefore likely to be depleted by plants and microbes. The depletion was probably compensated by release of $\mathrm{P}$ from $\mathrm{HCl}$ $\mathrm{P}$, citrate-P and phosphatase $\mathrm{P}$ by root or microbial exudates (Tarafdar and Claassen, 1988). Similarly, Hassan et al. (2012) reported that various legumes depleted $\mathrm{P}$ pools considered to be not readily available, probably by inducing transformation into available $\mathrm{P}$ pools. The strong increase in MBP from Part A to Part B particularly in the fertilizer treatments can be explained by $\mathrm{C}$ supply by roots (Jiang-shan et al., 2005). The increase was greater in fertilizer than straw treatments because in the latter, MBP was already high at the end of Part A.

In the cores, microbial growth was stimulated by straw addition. We had expected that MBP would increase more in the cores than in the pots where roots supplied the $\mathrm{C}$. However, this was not the case, suggesting that supply of readily available $\mathrm{C}$ by roots and straw was similar. Mature wheat straw contains a high proportion of structural $\mathrm{C}$ which is only slowly decomposable and may not have been decomposed during the three weeks in Part B. In contrast to the pot experiment, resin $\mathrm{P}$, phosphatase$\mathrm{P}$ and $\mathrm{CaCl}_{2}-\mathrm{P}$ increased from Part A to Part $\mathrm{B}$ in the cores. In the pots, $\mathrm{P}$ from these pools would be taken up by plants and thus removed from the soil. The increase in resin $\mathrm{P}$ and $\mathrm{CaCl}_{2}-\mathrm{P}$ in the cores suggests that $\mathrm{P}$ released from $\mathrm{HCl}-\mathrm{P}$ and citrate-P remained available in absence of plants. The increase in phosphatase-P indicates formation of phosphatase-labile organic $\mathrm{P}$ by microbes.

In the Hedley $\mathrm{P}$ fractionation soil is shaken sequentially with different extractants and it is assumed that $\mathrm{P}$ released by the previous extractant is removed before the next extractant is added (Hedley et al., 1982). In the DeLuca method used here, soil is shaken simultaneously with the different extractants (DeLuca et al., 2015). Therefore HCl-P is likely to include $\mathrm{P}$ extractable with citrate, phosphatase or $\mathrm{CaCl}_{2}$. As weakest extractant, $\mathrm{CaCl}_{2}-\mathrm{P}$ will include little or no $\mathrm{P}$ detectable with the other extractants. Unlike the original DeLuca method, we also measured MBP. It is a small pool (5-40 $\mathrm{mg} \mathrm{kg}^{-1}$ ), but our study shows that it is a highly dynamic pool that responds to $\mathrm{P}$ addition as well as $\mathrm{C}$ input in form of rhizodeposits or straw. The strong response of MBP to $\mathrm{C}$ input by plants or residues is in agreement with other studies (Bradford et al., 2013, Malik et al., 2013). Although MBP increased during plant growth in our study, it is considered to be a potentially plant available P pool (Balota $e t$ al., 2003). MBP in the rhizosphere has been shown to correlate with plant P uptake (Solaiman et al., 2007). Therefore it should be included in methods for determining biologically available P pools. 


\section{Conclusions}

The study showed that $\mathrm{P}$ pools assessed with the DeLuca method are influenced by $\mathrm{P}$ addition rate and can be depleted by plants and microbes. Our findings highlight the importance of MBP as dynamic P pool particularly when microbial growth is stimulated by root exudates or residue addition. Future studies could employ 33P labelled fertilizer or residues to trace amended $\mathrm{P}$ into $\mathrm{P}$ pools and plants.

\section{Acknowledgements}

Khuyen Thi Kim Hoang thanks the Vietnam International Education Development (VIED) for providing the postgraduate scholarship.

\section{References}

Alamgir, M., Marschner, P. 2016. Changes in P pools over three months in two soils amended with legume residues. J. Soil Sci. Plant Nutr. 16, 76-87.

Alamgir, M., McNeill, A., Tang, C., Marschner, P. 2012. Changes in soil $P$ pools during legume residue decomposition. Soil Biol. Biochem. 49, 70-77.

Balemi, T., Negisho, K. 2012. Management of soil phosphorus and plant adaptation mechanisms to phosphorus stress for sustainable crop production: a review. J. Soil Sci. Plant Nutr. 12, 547-562.

Balota, E.L., Colozzi-Filho, A., Andrade, D.S., Dick, R.P. 2003. Microbial biomass in soils under different tillage and crop rotation systems. Biol. Fertil. Soils. 38, 15-20.

Bradford, M.A., Keiser, A.D., Davies, C.A., Mersmann, C.A., Strickland, M.S. 2013. Empirical evidence that soil carbon formation from plant inputs is positively related to microbial growth. Biogeochemistry. 113, 271-281.
Bremner, J., Breitenbeck, G.A. 1983. A simple method for determination of ammonium in semimicroKjeldahl analysis of soils and plant materials using a block digester. Comm. Soil Sci. Plant Anal. 14, 905-913.

Chatterjee, D., Datta, S., Manjaiah, K. 2014. Fractions, uptake and fixation capacity of phosphorus and potassium in three contrasting soil orders. J. Soil Sci. Plant Nutr. 14, 640-656.

Ciampitti, I.A., Picone, L.I., Rubio, G., García, F.O. 2011. Pathways of Phosphorous Fraction Dynamics in Field Crop Rotations of the Pampas of Argentina. Soil Sci. Soc. Am. J. 75, 918-926.

Dalal, R.C. 1979. Mineralization of Carbon and Phosphorus from Carbon-14 and Phosphorus-32 Labelled Plant Material Added to Soil. Soil Sci. Soc. Am. J. 43, 913-916.

DeLuca, T., Glanvile, H., Harris, M., Emmett, B., Pingree, M., de Sosa, L., Cerda-Moreno, C., Jones, D. 2015. A novel biologically-based approach to evaluating soil phosphorus availability across complex landscapes. Soil Biol. Biochem. 88, $110-119$.

Gee, G.W., Or, D. 2002. 2.4 Particle-size analysis. Methods of soil analysis. Part 4, 255-293.

Hanson, W. 1950. The photometric determination of phosphorus in fertilizers using the phosphovanado-molybdate complex. J. Sci. Food Agric. 1, 172-173.

Hassan, H.M., Marschner, P., McNeill, A., Tang, C. 2012. Growth, P uptake in grain legumes and changes in rhizosphere soil $\mathrm{P}$ pools. Biol. Fertil. Soils. 48, 151-159.

Hedley, M.J., Stewart, J., Chauhan, B. 1982. Changes in inorganic and organic soil phosphorus fractions induced by cultivation practices and by laboratory incubations. Soil Sci. Soc. Am. J. 46, 970-976. 
Jiang-shan, Z., Jian-fen, G., Guang-shui, C., Wei, Q. 2005. Soil microbial biomass and its controls. J. For. Res. 16, 327-330.

Kouno, K., Tuchiya, Y., Ando, T. 1995. Measurement of soil microbial biomass phosphorus by an anion exchange membrane method. Soil Biol. Biochem. 27, 1353-1357.

Malik, M., Khan, K., Marschner, P. 2013. Microbial biomass, nutrient availability and nutrient uptake by wheat in two soils with organic amendments. J. Soil Sci. Plant Nutr. 13, 955-966.

Maltais-Landry, G., Frossard, E. 2015. Similar phosphorus transfer from cover crop residues and water-soluble mineral fertilizer to soils and a subsequent crop. Plant Soil. 393, 193-201.

Marschner, P., Hatam, Z., Cavagnaro, T. 2015. Soil respiration, microbial biomass and nutrient availability after the second amendment are influenced by legacy effects of prior residue addition. Soil Biol. Biochem. 88, 169-177.

Miranda, K.M., Espey, M.G., Wink, D.A. 2001. A rapid, simple spectrophotometric method for simultaneous detection of nitrate and nitrite. Nitric Oxide. 5, 62-71.

Murphy, J., Riley, J.P. 1962. A modified single solution method for the determination of phosphate in natural waters. Anal. Chim. Acta. 27, 31-36.

Noack, S.R., McLaughlin, M.J., Smernik, R.J., McBeath, T.M., Armstrong, R.D. 2012. Crop residue phosphorus: speciation and potential bio-availability. Plant Soil. 359, 375-385.

Ohno, T., Zibilske, L.M. 1991. Determination of low concentrations of phosphorus in soil extracts using malachite green. Soil Sci. Soc. Am. J. 55, 892-895.

Olsen, S., Sommers, L., Page, A. 1982. Methods of soil analysis. Part 2. Chemical and microbiological properties of Phosphorus. ASA Monograph. 403-430.
Pierzynski, G.M., Logan, T.J., Traina, S.J., Bigham, J.M. 1990. Phosphorus Chemistry and Mineralogy in Excessively Fertilized Soils: Quantitative Analysis of Phosphorus-rich Particles. Soil Sci. Soc. Am. J. 54, 1576-1583.

Shen, J., Yuan, L., Zhang, J., Li, H., Bai, Z., Chen, X., Zhang, W., Zhang, F. 2011. Phosphorus dynamics: from soil to plant. Plant Physiol. 156, 997-1005.

Solaiman, Z., Marschner, P., Wang, D., Rengel, Z 2007. Growth, P uptake and rhizosphere properties of wheat and canola genotypes in an alkaline soil with low P availability. Biol. Fertil. Soils. $44,143$.

Tarafdar, J., Claassen, N. 1988. Organic phosphorus compounds as a phosphorus source for higher plants through the activity of phosphatases produced by plant roots and microorganisms. Biol. Fertil. Soils. 5, 308-312.

Tiessen, H., Ballester, M.V., Salcedo, I. 2011. Phosphorus and Global Change. In: Phosphorus in Action. Bünemann E., Oberson A. and Frossard E. (eds), pp 459-471. Springer Berlin Heidelberg.

Walkley, A., Black, I.A. 1934. An examination of the Degtjareff method for determining soil organic matter, and a proposed modification of the chromic acid titration method. Soil Sci. 37, 29-38.

Wilke, B.M. 2005. Determination of chemical and physical soil properties. In: Monitoring and Assessing Soil Bioremediation. Margesin R. and Schinner F. (eds) pp 47-95. Springer Berlin Heidelberg.

Xue, R., Shen, Y., Marschner, P. 2016. Low soil water content during plant growth influences soil respiration and microbial biomass after plant removal and rewetting. J. Soil Sci. Plant Nutr. 16, 955-966. 
Changes in P pools in soil amended with straw and inorganic P. 1098 
Changes in P pools in soil amended with straw and inorganic P. 1100 
Changes in P pools in soil amended with straw and inorganic P. 1101 